\title{
Various Online Geography Learning Assessment with Critical Spatial Thinking during The Covid-19 Pandemic in Indonesian High Schools
}

\author{
Muhammad Nursa'ban', Muhsinatun Siasah $\mathbf{M}^{\mathbf{2}}$, Nursida Arif ${ }^{3}$ \\ ${ }^{123}$ Geography Education Study Program, Universitas Negeri Yogyakarta, Indonesia \\ ${ }^{1}$ m_nursaban@uny.ac.id, ${ }^{2}$ muhsinatun_siasah@uny.ac.id, ${ }^{3}$ nursida.arif@uny.ac.id
}

\begin{abstract}
The main competence of students learns geography is critical spatial thinking. The prolonged condition of Pandemic Covid-19 forced online learning. One of the problems is the learning assessment process. This study aims to find various alternative geographic learning assessments with Critical Spatial Thinking, which are comprehensive and accountable in Indonesian high schools. A survey of 50 geography teachers in Yogyakarta and a deep literature study was used in this study. The dimensions of the study include 1) analysis of the structure of the geography curriculum to map the basic competencies of geography material and the online learning process that can be carried out. 2) The variation of the assessment uses a learning evaluation approach in the curriculum. Data were analyzed descriptively to get an overview and basis for confirmation of various online geography learning assessment. The results of the study showed that: 1) almost all the basic competencies in learning geography in class X, XI, and XII could potentially be assessed online. Online test assessments for knowledge competencies can be done with more variations than affective competencies and skills. 2) Variations of online assessments that can be used include tests and non-tests. The kinds of tests used were oral, deed, and written. Most of the non-test assessments were used for attitude and skill assessment with more than five types of assessment. The main obstacle to the assessment of learning from the teacher is developing devices that must information technology capabilities.
\end{abstract}

Keywords: assessment, online learning, geography, critical spatial thinking

\section{Introduction}

The Covid-19 pandemic since the beginning of March 2020 in Indonesia has changed the realization of education in formal and non-formal schools at all levels from conventional learning in class to being distant, where teachers and students interact with each other in different places. Furthermore, the Indonesian Ministry of Education issued a regulation asking all learning processes to switch to online or online learning during the pandemic. The disagreement of opinion among education experts regarding the pros and cons of this decision does not prevent students from continuing to teach students at home through direct assistance of parents and teachers online. All teachers are required to adapt to the circumstances of the learning process, including geography teachers in SMA.

Initial studies through interviews with 25 geography teachers obtained an overview that the main problem faced is the difficulty of designing learning outcome assessments on cognitive, affective, and skill aspects as basic competencies of online graduates. Limitations of supporting facilities for online learning and the readiness of parents to "cooperate" with teachers while accompanying their children to strengthen the transfer of knowledge. Busy parents, understanding the curriculum, and learning sometimes make online assessments more difficult. Some of them, only about $10 \%$, could design online learning through independent learning or attend training but have not been trained in full online conditions such as during this pandemic. They can operate online tools but do not yet understand the appropriate assessment design according to the characteristics of online learning.

Competence of graduates after studying geography in a curriculum that calls for critical spatial thinking (CST) abilities which are in line with Higher-Order Thinking Skills (HOTS). Critical 
Spatial Thinking as the core of geography science stems from the concept of spatial thinking from the National Research Council United States [1]; on the element I, namely how to analyze the spatial organization of people, places, and the environment on the entire surface of the earth. Spatial thinking represents the ability to transform knowledge by manipulating, reconstructing, and navigating physical objects to achieve academic and intellectual success [2] [3] [4]. The ability to extrapolate and elaborate from the existing relationships between spatial concepts, and about the relationship between theory and generalization in geography is expected to be a competence that emphasizes the existence of integrated spatial interconnections between physiographic conditions and human activities [5]. The integration of CST skills in geography learning will help students to achieve overall learning goals [6].

The concept of critical spatial thinking as reflective, skeptical, or analytical, the implication is that the successful application of spatial perspective can never be memorized, it will always engage the students' minds through active questioning and examination of assumptions, techniques, and data [7]. CST involves a deeper level of understanding of spatial concepts [8]. Another opinion explains that CST is a constructive combination of critical thinking and spatial thinking [9]. Other experts suggest that the integration of CST in geography is in the process of combining spatial concepts with geographic principles to guide and inform reasoning [10]. The practice of critical thinking is carried out in a context or situation where the interpretation of geographic information requires thinkers to become producers or consumers of that information [11]. A critical spatial thinker understands problems, comes up with solutions, and communicates effectively about processes, patterns, and results in geographic contexts by applying their knowledge to scale, location, distance, and other spatial concepts [12]. The concept of critical spatial thinking will be explained in the context of the factors that are relevant to the implementation of geographic learning, especially its integration in geographic materials containing HOTS. Spatial thinking underlies the standard intellectual structure of geography that shows the possibilities and power of inculcating critical spatial thinking into a discipline. Teachers who have been able to understand the benefits of spatial thinking in education will appreciate it in geography through critical spatial thinking [6].

Critical spatial thinking in the Indonesian national curriculum is presented in the form of a spatial representation formulated from the relationship between human and environmental systems in three dimensions [13]. A geographical perspective on the dynamics of the physical and community environment will be seen from the aspects of spatial integration and spatial interdependence both between places and between scales. This perspective can be manifested in real or abstract forms (and / or representations) either visually, verbally, mathematically, digitally, or in a (cognitive) mindset."

The scheme of geographic competence demands as a discipline taught at the high school level, explicitly, the operational spatial representation has not been explained in more detail, so that the description of learning outcomes in the form of critical spatial thinking is still being debated.

On the other hand, learning as an educational process in Indonesia is directed into Higher Order Thinking Skills (HOTS) [14] [15]. The characteristics of the learning are shown as follows: 1) focuses on questions, 2) analyzes/assesses arguments and data, 3) defines concepts, 4) determines conclusions, 5) uses logical analysis, 6) processes and applies information, 7) uses the information to solve the problem. The national curriculum expects education in Indonesia to produce knowledgeable students who are critical and creative in their thinking and able to compete at the international level. Higher-order thinking skills are based on lower-level skills such as discrimination, simple application and analysis, and cognitive strategies and are linked to prior knowledge of the subject matter content. Appropriate teaching strategies and learning environments facilitate their growth as do student persistence, self-monitoring, and an open, flexible attitude [16].

The Ministry of Education and Culture has promoted that HOTS is not only used at the assessment level but must be implemented in the learning process. Teachers as the spearhead of change can change the mindset and learning strategies that were originally teacher-centered to student-centered. Teachers are expected to be more creative and innovative in presenting subject matter. The creation of productive, creative, and innovative Indonesian people can be realized 
through the implementation of learning that can be carried out in various fields by using critical and creative thinking skills.

In the cognitive domain of Bloom's taxonomy, graduates can create, so students must be continuously trained to produce something new. HOTS encourage the ability to think critically, logically, reflectively, metacognitively, and think creatively, which are higher-order thinking skills. In HOTS geography learning can be integrated through various aspects of learning components such as materials, methods, media, and assessments.

The integration of critical spatial thinking with HOTS in geography lessons aims to equip students with the ability to find and understand the earth's spatial phenomena. The curriculum describes that these competencies apply a holistic approach to geography learning by developing understanding and skills about spatial representation. Various concepts of spatial thinking impose boundaries that intersect with critical spatial thinking in geographic curricula [17]. Critical spatial thinking is a way of interpreting geographical phenomena expressed in written and / or abstract form to describe the dynamics of integration and interdependence of spatial environments [18].

Different conditions found that the conception of critical spatial thinking with HOTS has not been understood and is still a debate between teachers as practitioners and developers of geography education as experts. This description implies that the ongoing learning of geography still emphasizes conceptual and procedural skills. Initial knowledge has not led to factual and metacognitive aspects of critical spatial thinking with HOTS content. The teachers have difficulty designing a variety of online learning process assessments. This study aims to identify various alternative assessments of geography learning with Critical Spatial Thinking, which are comprehensive and accountable in high school. The dimensions of the study include 1) analysis of the geography curriculum structure to map the basic competencies of geography materials and the online learning process that can be done. 2) Variation of assessment using the learning evaluation approach in the curriculum.

\section{Method}

This study is survey research to collect data on variables at the same time. A survey using a questionnaire of 50 geography teachers in Yogyakarta and a deep literature study was used in this study. By the research objectives, the survey variables include 1) analysis of the structure of the geography curriculum to map the basic competencies of geography material and the online learning process that can be carried out. 2) The variation of the assessment uses a learning evaluation approach in the curriculum. Data were analyzed descriptively to obtain an overview and basis for confirmation of various online geography learning assessment. The unit of analysis in this research is a descriptive generalization of the sample phenomenon. The basis for this survey research is trend studies.

The percentage technique was used for data analysis. This technique can see how much the frequency of respondents' answers tends to be and the phenomena in the field. This step is also carried out to see the size of the proportion of each answer to each question so that the data that is processed is easy to analyze. The data obtained through the instrument will be checked, then classified based on criteria so that it is easily tabulated based on the frequency of answers, then calculating the percentage. Furthermore, the data is presented via tables and interpreted.

\section{Result and Discussion}

\subsection{Structure of the geography curriculum to map the basic competencies of geography material and the online learning process that can be carried out.}

The curriculum structure that describes the basic competencies in each subject matter that can be online is obtained through the analysis of essential materials. The descriptions of the instruments for obtaining the essential geographic material data are in the two sub-variables 
developed, namely: First, the organization of online learning as seen from the indicators of need analysis and the target audience. Second, namely the learning course design, the second sub variable is further broken down into four indicators, namely: learning objectives, sequencing, instructional and delivery strategy, and evaluation [19]. Based on these indicators, the essential and main material is obtained.

\section{a. Organizing online learning}

The first sub variable indicator is to conduct a need analysis of the respondents. Almost all teacher respondents gave similar answers, that before designing online learning it is necessary to determine whether training is required to fill a gap in professional knowledge and skills; and this online learning is the best solution for transferring competency standards of graduates in the aspects of knowledge, attitudes, and skills. The teachers as respondents stated that the goal of learning is the main thing. Likewise in online learning, even though it has different situations and activities from face-to-face learning, however, the ultimate goal of learning is required to be similar. This consideration is important, considering that in the field many factors can affect the failure of the learning process, such as unsupportive surroundings, school support, and individual capacity.

Environmental factors in a large scope concern policy support in the learning process. During this Covid-19 pandemic, not all elements of education policymakers made similar policies among schools in a region. Policymakers provide more opportunities for face-to-face learning with strict health protocols. Meanwhile, in a closer scope, the rules, norms, understanding of the family, the availability of tools and activities of the people around the community sometimes do not support online learning. Students are very distracted because while studying (if the tools are available) while doing other family activities, people going back and forth around, to the noise of conversations and sounds from electronic devices. The availability of tools such as computers, cellular phones, and internet networks greatly determines the learning process can be carried out. If teachers or school policies design learning through an exclusive learning management system application, then the next problem is an adaptation to the application.

Another problem, namely the absence of school support. This lack of support can be formally manifested in the form of school policies and school climate. The teachers convey that sometimes online learning is not considered the same form of learning as face-to-face, as a result, it is assessed financially lower than learning in normal times. Some teachers even stated that their schools were not given additional costs for designing online learning applications, converting manual devices to digital, and eliminating attendance incentives. School policies to support the online learning process during this pandemic should be firm and written, but because this disaster came suddenly, there was unpreparedness. Some of the respondent teachers wrote that another support that sometimes escapes school support is facilitation in designing online learning and the provision of learning tools and facilities. These various school support problems sometimes reduce teacher motivation to service learning for students.

Individual capacities in designing online learning vary among teachers. Some junior teachers have a more responsive response than seniors in the conversion of learning platforms into technology applications. These juniors are familiar with information technology, especially in the digital transformation process of the learning space. This condition, for senior teachers, is a burden in itself. They must learn to adapt to unusual technological applications. This limited individual ability makes it difficult and takes a long time to convert learning online. Collaboration between junior and senior teachers is needed in this case, in addition to the full support of the school. Limited space for movement and mediocre abilities can make this collaboration difficult. Not all of these individual capacity problems are related to learning problems, but also on teacher performance. Often, performance portrayals result from a lack of support in the work environment, such as bad data, outdated tools, or poor incentives. Also, not all learning problems can be overcome through e-learning. It is very important to understand whether e-learning is appropriate for the identified learning objectives.

If online learning is one of the alternative solutions to be used, an analysis of the needs of students is needed as the target audience. Several factors are used as the basis for determining the online learning needs of students, including referring to five indicators [19], namely region or geographic area in which learners reside; Kind of organization or institution in which learners 
work, and their professional role (s) within them; Learners' previous knowledge and expertise on the subject; learners' computer skills and technical expertise; and, the amount of time available for e-learning and the learning context.

The teachers as respondents agreed that these factors had to be well measured and resulted in the readiness of the students. In order from high to low, the teacher's response to online learning factors based on the needs of students is described as follows: the first step is to identify the level of knowledge of the learners. In general, students who have access to technology to meet the target material in the curriculum can more easily accept changes in learning from face to face to online. On the other hand, other students who have little access need training and supporting facilities. The second aspect is synchronizing the application and habituation of students with time and programming language on the online learning platform. Students' initial skills in computers will help determine the complexity of interactive activities in learning. This information affects the amount of content that will be provided and the need to divide the content into small units. Besides, it will help to identify specific learning objectives for each target audience group. The consideration for identifying the needs of this target audience is that the learning experience in online learning is created by the students themselves. Students can create their learning atmosphere that is comfortable and as desired. All learning processes are determined by the teacher starting from the time, place, atmosphere, method, and others, while students will be able to learn independently. Several internal and external factors will influence the success of online learning conducted by students. Internal factors that can influence are intelligence, high curiosity, motivation, personality, and so on. Meanwhile, external factors that can affect online learning are the technology used, the environment, the speed of internet access, and so on. In online learning, every student needs to create a teacher presence, which can be used as a control for himself. When students have created teacher presence, students will be able to control their own learning pace. When the teacher's role does not exist, it can allow student laziness which can result in not running online learning according to schedule.

\section{b. Learning Course Design}

Starting the design of learning materials by determining learning objectives in the form of essential geography materials, then sequencing the material into the subject matter of each class, learning methods, and evaluation.

The results of the survey and in-depth interviews with respondents indicated that the teachers agreed to use geography essential material during online learning referring to the geographic scope of high school in the national curriculum regarding core competencies and basic competences in geography lessons. The essential geographic description consists of seven materials as presented in Table 1.

Table 1. Essential materials for high school geography that can be online

\begin{tabular}{|c|c|c|c|}
\hline & & ESSENTIAL MATERIALS & Class \\
\hline & $\begin{array}{l}\text { Literacy and } \\
\text { Geography Skills }\end{array}$ & $\begin{array}{l}\text { 1. Basic knowledge of geography and its application in } \\
\text { everyday life. }\end{array}$ & Kelas X \\
\hline & $\begin{array}{l}\text { Physical } \\
\text { Geography }\end{array}$ & $\begin{array}{l}\text { 2. The dynamics of the planet Earth as living space. } \\
\text { 3. Geosphere dynamics and their impact on life }\end{array}$ & $\mathrm{X}$ \\
\hline & Human Geography & $\begin{array}{l}\text { 4. The dynamics of the population in Indonesia for } \\
\text { development are based on geographical concepts, } \\
\text { principles, and approaches. } \\
\text { 5. National cultural diversity as a national identity based on } \\
\text { distribution patterns, uniqueness, and interaction } \\
\text { processes to increase national harmony. }\end{array}$ & XI \\
\hline & $\begin{array}{l}\text { Environmental } \\
\text { Interaction }\end{array}$ & $\begin{array}{l}\text { 6. The condition of Indonesia's territory and its strategic } \\
\text { value as a world maritime axis. } \\
\text { 7. Distribution of strategic resources in Indonesia and their } \\
\text { use following the principles of sustainable development. } \\
\text { 8. Mitigation and adaptation of natural disasters based on } \\
\text { local wisdom values and modern technological } \\
\text { approaches. }\end{array}$ & $\mathrm{XI}$ \\
\hline & $\begin{array}{l}\text { Regional } \\
\text { Geography }\end{array}$ & $\begin{array}{l}\text { 9. Regional and zoning concepts in national development } \\
\text { planning }\end{array}$ & XI \\
\hline
\end{tabular}




\begin{tabular}{llc}
\hline & \multicolumn{1}{c}{ ESSENTIAL MATERIALS } & Class \\
\cline { 3 - 3 } & $\begin{array}{l}\text { 10. Patterns of distribution and spatial interaction between } \\
\text { rural and urban areas and between regions. } \\
\text { 11. Regionalization of geographic phenomena based on } \\
\text { location, distribution, economic and technological } \\
\text { development }\end{array}$ & XII \\
6. Global Connections \\
$\begin{array}{l}\text { and Change } \\
\text { Management } \\
\text { Geographical use } \\
\text { for development }\end{array}$ & $\begin{array}{l}\text { developing countries to establish mutually beneficial } \\
\text { cooperation }\end{array}$ & Basics of mapping, Remote Sensing and Geographical \\
Information Systems (GIS & XII \\
\hline
\end{tabular}

The results of the study show that almost all basic competencies in geography learning can potentially be assessed online. Based on the grouping of geography essential material, subject, and sub-subject sequencing is carried out to facilitate the achievement of student competencies in the aspect of knowledge. An overview of the subject in general for each class is shown in Table 2.

Table 2. Subjects of High School Geography

\begin{tabular}{|c|c|c|}
\hline \multicolumn{3}{|c|}{ Subject } \\
\hline Class X & Class XI & Class XII \\
\hline $\begin{array}{l}\text { 1. Basic knowledge of } \\
\text { geography }\end{array}$ & $\begin{array}{l}\text { 2. Indonesia's geographic } \\
\text { potential }\end{array}$ & $\begin{array}{l}\text { 3. Mapping and geographic } \\
\text { information systems for } \\
\text { development }\end{array}$ \\
\hline 4. Geographical research steps & $\begin{array}{l}\text { 5. Distribution and strategic } \\
\text { resource management } \\
\text { systems }\end{array}$ & $\begin{array}{l}\text { 6. Remote sensing for land use } \\
\text { and transportation }\end{array}$ \\
\hline 7. Introduction to the earth & 8. Population dynamics & $\begin{array}{l}\text { 9. Spatial interactions of villages } \\
\text { and cities }\end{array}$ \\
\hline $\begin{array}{l}\text { 10. The dynamics of the } \\
\text { lithosphere and their impact } \\
\text { on life }\end{array}$ & $\begin{array}{l}\text { 11. Indonesian cultural } \\
\text { diversity }\end{array}$ & $\begin{array}{l}\text { 12. Study of world regions } \\
\text { and connectivity between } \\
\text { spaces }\end{array}$ \\
\hline $\begin{array}{l}\text { 13. Atmospheric } \\
\text { dynamics and their impact on } \\
\text { life }\end{array}$ & $\begin{array}{l}\text { 14. National food } \\
\text { security efforts }\end{array}$ & $\begin{array}{l}\text { 15. Regional studies and } \\
\text { interactions between } \\
\text { developing and developed } \\
\text { countries }\end{array}$ \\
\hline $\begin{array}{l}\text { 16. Dynamics of the } \\
\text { hydrosphere and their impact } \\
\text { on life }\end{array}$ & $\begin{array}{l}\text { 17. Regional and } \\
\text { zoning concepts }\end{array}$ & \\
\hline $\begin{array}{l}\text { 18. Distribution of flora } \\
\text { and fauna in Indonesia and } \\
\text { the world }\end{array}$ & Disaster mitigation & \\
\hline
\end{tabular}

Most respondents stated that the method of learning geography online as an instructional space and delivery strategy can be designed normatively that is not different from other subjects in the social interest family. The difference lies in the addition of studies according to the characteristics of geography subjects. In more detail, the prediction of geography learning content in the $21 \mathrm{st}$ century, namely: (1) emphasizing geographic perspectives (spatial thinking and world-ecology); (2) the main core of learning (Location, Place, Human-Environment Interaction, Movement, and Area); and (3) emphasizes core skills (asking geographic questions, obtaining geographic information, presenting geographic information, analyzing geographic information, and developing and testing geographic generalizations) [20].

This paradigm is substantially relevant to the opinion that geography learning in the $21 \mathrm{st}$ century focuses on scale, thinking systems, and critical thinking to solve social and environmental spatial problems and their sustainability through the role of geospatial technology [20] [21] [22]. Learning geography in school is often identified with memorizing the names of capitals, landscapes, and oceans, even though this general conception is only a small picture of geography 
studies [23]. He added that geography is a complex discipline with a focus on the characteristics, relationships, and spatial patterns of human and natural activities. Geography teaches about culture, geopolitics, natural systems, distribution of resources and their use, and mapping spatial data to better understand the world.

Geography learning contains critical spatial thinking interpreted as a process to equip students by placing spatial thinking into the main characteristics of subjects. The intellectual structure of the geography standard with the spatial thinking perspective is designed to achieve the Core Competencies, as stated in the Graduate Competency Standards and Geographic Competency Standards. The implementation of geography learning with critical spatial thinking in schools in this context is not an addition to the curriculum, but rather as a "missing link" in interpreting the content of the geography curriculum based on its essence.

\subsection{Variation of the assessment uses a learning evaluation approach in the curriculum}

Assessment is carried out to obtain an overview of learning outcomes. Learning outcomes are essentially changing in student behavior because of the learning process or after receiving learning experiences [24] [25] [26]. The results of studying geography around the world have different points of view and focus [27]. There are four standards because of studying geography [28], namely: 1). Doing Geography: The Geographic Lens on the World. 2) Looking at the World in Multiple Ways: Geographic Perspectives. 3) Knowing about the World: Geographic Content Knowledge and 4) Asking and Answering Geographic Questions about the World: Geographic Skills. The four competency structures from Heffron are interconnected and complementary as a geography graduate standard. The first competency is the applicative ability because of the integration between attitude competencies in the form of geographic perspectives, content knowledge competencies, and skills competencies. The description of these competencies is in line with the learning outcomes of Bloom, who designed the scope of learning outcomes including cognitive, affective, and psychomotor aspects.

Under the policy on national assessment standards [13], there are three areas of assessment for learning outcomes with critical spatial thinking, namely attitudes, knowledge, and skills. Assessment of aspects of attitudes to build students' geographic awareness of environmental conditions after studying geography. Researchers call this skill a form of "attitude to build geographical awareness". The knowledge (cognitive) aspect assesses students' understanding of geography materials in the curriculum through geography critical thinking skills. Researchers call this learning outcome ability a form of "geographic critical thinking". The assessment of the psychomotor aspects (skills) measures students' behavior in calculating, measuring, or applying spatial representation tools in geography material.

Respondents answered questions from the survey about the types of assessments that can be carried out during online learning with a variety of assessment variations. Based on the form, this assessment is divided into two, namely test and non-test.

Table 3. Various online assessments

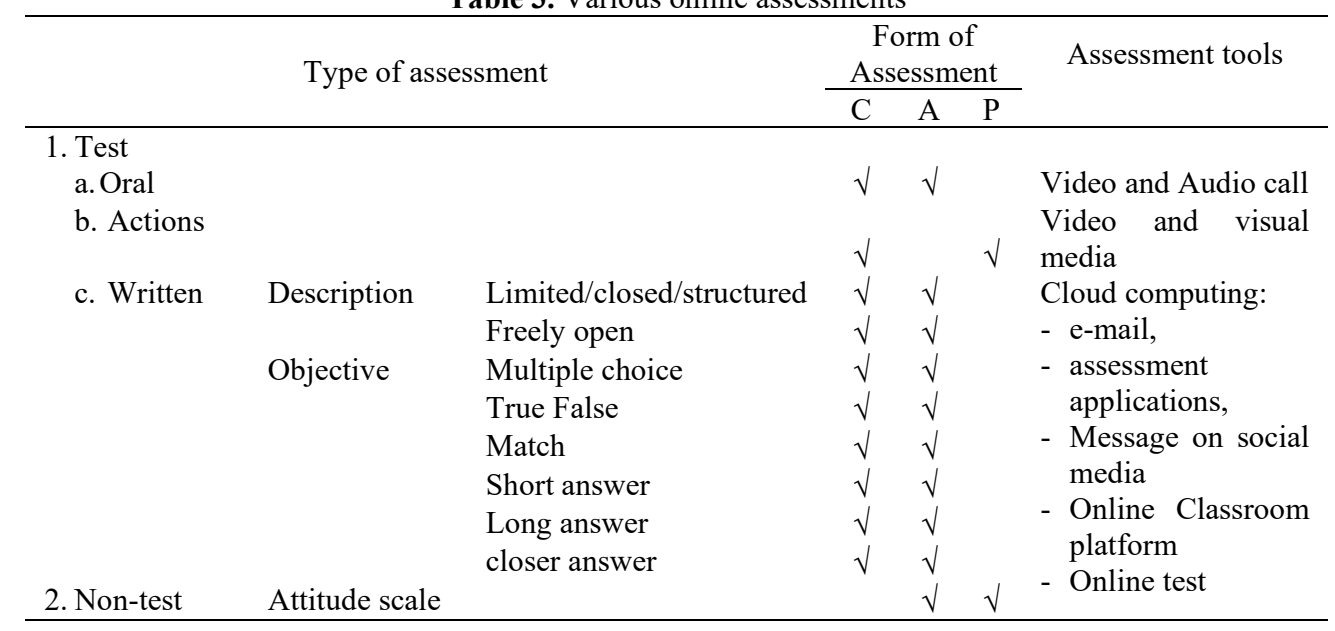




\begin{tabular}{|c|c|c|c|c|}
\hline \multirow[t]{2}{*}{ Type of assessment } & \multicolumn{3}{|c|}{$\begin{array}{c}\text { Form of } \\
\text { Assessment }\end{array}$} & \multirow[t]{2}{*}{ Assessment tools } \\
\hline & $\mathrm{C}$ & $\mathrm{A}$ & $\mathrm{P}$ & \\
\hline Checklist & & $\sqrt{ }$ & $\sqrt{ }$ & \\
\hline Questionnaire & $\sqrt{ }$ & $\sqrt{ }$ & $\sqrt{ }$ & \\
\hline Anecdotal & & & & \\
\hline Notes & & $\sqrt{ }$ & $\sqrt{ }$ & \\
\hline Portfolio & & $\sqrt{ }$ & $\sqrt{ }$ & \\
\hline School & & & & \\
\hline records & & $\sqrt{ }$ & $\sqrt{ }$ & \\
\hline Journal & & $\sqrt{ }$ & $\sqrt{ }$ & \\
\hline Work & & & & \\
\hline snippets & & & $\sqrt{ }$ & \\
\hline Project & & & $\sqrt{ }$ & \\
\hline Product & & & $\sqrt{ }$ & \\
\hline Self- & & & & \\
\hline Assessment & & $\sqrt{ }$ & & \\
\hline Peer & & & & \\
\hline Assessment & & $\sqrt{ }$ & & \\
\hline
\end{tabular}

\section{Conclusion}

The Covid-19 pandemic has had a profound impact on the assessment process and outcomes of all subjects. The results of the study showed that: 1) almost all the basic competencies in learning geography in class X, XI, and XII could potentially be assessed online. Online test assessments for knowledge competencies can be done with more variations than affective competencies and skills. 2) Variations of online assessments that can be used include tests and non-tests. The kinds of tests used were oral, deed, and written. Most non-test assessments were used for attitude and skill assessment with more than five types of assessment. The main obstacle to the assessment of learning from the teacher is developing devices that require information technology capabilities.

\section{Acknowledgment}

The researcher expressed gratitude to the Graduate program of UNY for funding this study as part of community service activities.

\section{References}

[1] National Research Council, Learning to think spatially GIS as a support system in the K-12 curriculum, Washington, DC: National Academy Press, 2006.

[2] Gold, A. U., Pendergast, P. M, Ormand, C. J, Budd, D.A., Stempien, J. A., Mueller, K. J. and Kravitz, K. A. , "Improving spatial thinking skills among undergraduate geology students through short online training exercises," International Journal of Science Education, pp. 14(2), 668-683., 2018.

[3] Newcombe, N. S. and Shipley, T. F. , Thinking about spatial thinking: new typology, new assessments, New York: Springer, 2015.

[4] Uttal, D.H., Miller, D.I. and Newcombe, N.S. , "Exploring and enhancing spatial thinking: Links to achievement in science, technology, engineering, and mathematics?," Current Directions in Psychological Science, pp. 22 (5), 367-373, 2013.

[5] A. Bonnet, What is geography?, Los Angeles: Sage Publication, 2008.

[6] I. Jo and S. W. Bednarz, "Dispositions toward teaching spatial thinking through geography: 
conceptualization and an exemplar assessment," Journal of Geography, pp. 113: 5. 198-207, 2014.

[7] M. F. Goodchild and D. Janelle, "Toward critical spatial thinking in the social sciences and humanities," GeoJournal, p. 75. 3-13, 2010.

[8] H. Miller and M. Goodchild, "Data-driven geography," GeoJournal, pp. 80 (4). 449-461, 2014.

[9] M. Kim and R. Bednarz, "Effects of a GIS course on self-assessment of Spatial Habits of Mind (SHOM)," Journal of Geography, pp. 112 (4), 165-177, 2013.

[10] D. Sinton, "Critical spatial thinking," in International Encyclopedia of Geography, John Wiley \& Sons, Ltd, 2017..

[11] S. Metoyer and R. Bednarz, "Spatial thinking assists geographic thinking: evidence from a study exploring the effects of geospatial technology," Journal of Geography, pp. 116 (1), 20-33., 2017.

[12] B. Sharpe and N. Hyunh, "A review of geospatial thinking assessment in high school," in Geospatial technologies and geography education. advances in geographical and environmental sciences, Japan, Springer., 2015, pp. 169-180.

[13] M. Ministry of National Education of Indonesia, Regulation of ministry of national education number 23/2016, Jakarta, 2016.

[14] S. Y. Tan and S. H. Halili, "Effective teaching of higher-order thinking (HOT) in education," The Online Journal of Distance Education and E-Learning, , pp. 3(2), 41-47, 2015.

[15] A. Zohar, "Challenges in wide scale implementation efforts to foster higher order thinking (HOT) in science education across a whole wide system.," Thinking Skills and Creativity, pp. 10, 233-249, 2013.

[16] . L. . A. M. Pillay, C. . K. S. Singh, R. N. S. R. Harun and T. . S. M. Singh, "The Implementation of Higher Order Thinking Skills for Teaching and Learning," The Journal of Social Sciences Research, pp. 5, 668-675, 2018.

[17] J. Lee and R. Bednarz, "Components of spatial thinking: evidence from a spatial thinking ability test," Journal of Geography, p. 111. 15-26, 2012.

[18] M. Nursa'ban, K. Kumaidi and M. Mukminan, "Factors of Critical Spatial Thinking for a Geography Metacognition Assessment in Indonesian Senior High Schools," Review of International Geographical Education (RIGEO), pp. 10 ( 2), 186-204, 2020.

[19] FAO, "Part II - Designing an e-learning course," 2020. [Online]. Available: http://www.fao.org/3/i2516e/i2516e01.pdf.

[20] S. Bednarz, S. Heffron and N. Huynh, "A road map for 21st century geography education: Geography education research (A report from the Geography Education Research Committee of the Road Map for 21 st Century Geography Education Project)," Association of American Geographers, Washington, DC, 2013.

[21] J. Kerski, "Teaching geography in the twenty-first century: New Tools Are Available to Teach Geography in More Engaging, Dynamic, and Effective Ways," 2015. [Online]. Available: https://blogs.esri.com/esri/esri-insider/2015/01/26/teaching-geography-in-the-twenty-first-century/.

[22] E. Schell, K. J. Roth and A. Mohan, Road map for 21 st century geography education project instructional materials and professional development recommendations and guidelines for instructional materials and professional development in Geography Education, London: Routledge, 2013.

[23] L. Mohan, A. Mohan and D. Uttal, "Research on thinking and learning with maps and geospatial technologies.," in Geo progressions. Learning progressions for maps, geospatial technology, and spatial thinking, American Association of Geographer, 2015, pp. 9-21.

[24] N. Sujana, Learning outcomes assessment (Penilaian hasil belajar), Bandung: Rossda Karya, 2009.

[25] O. Hamalik, Curriculum and learning (Kurikulum \& pembelajaran), Jakarta: Bumi Aksara, 2013.

[26] W. Winkel, Instructional Psychology (Psikologi Pengajaran), Yogyakarta: Media Abadi, 2009.

[27] T. Beneker and J. (. Schee, "Future geographies and geography education," International Research in Geographical and Environmental Education, pp. 24(4), 287-293., 2015.

[28] S. Heffron, "GFL2! The updated geography for life: National geography standards, second edition," The Geography Teacher, p. 9 (2): 43-48, 2012. 